\title{
Epigeal aphidophagous predators and the role of alfalfa as a reservoir of aphid predators for arable crops
}

\author{
XAVIER PONS ${ }^{1}$, Eva NÚÑEZ², BELÉn LUMBIERRES ${ }^{1}$ and RAMON ALBAJES ${ }^{1}$ \\ ${ }^{1}$ Universitat de Lleida, Centre UdL-IRTA, Avda. Rovira Roure 191, 25198 Lleida, Spain; e-mails: xavier.pons@irta.es; \\ bel.lumbierres@pvcf.udl.es; ramon.albajes@irta.es \\ ${ }^{2}$ Consejeria de Agricultura y Alimentación, Gobierno de Aragón, Avda. Montañana 930, 50059 Zaragoza, Spain; \\ e-mail: enunnez@aragob.es
}

Key words. Alfalfa, aphid predators, Nabidae, Anthocoridae, Coccinellidae, Carabidae, Staphylinidae, Araneae

\begin{abstract}
The relative occurrence and seasonal abundance of aphidophagous predators (Insecta and Arachnida) were determined in alfalfa fields at two locations in the northeast Iberian Peninsula, using D-Vac and sweep-net sampling techniques. Among the insects, Heteroptera, Dermaptera, Neuroptera, Coleoptera and Diptera were found. The relative abundance of predators was similar at the two locations. Polyphagous predators were much more abundant than aphid specific species. Heteroptera were the most abundant order of insect predators: members of the Nabidae, Anthocoridae and Miridae were very common. Coleoptera were also abundant, represented mainly by the family Staphylinidae. Coccinellidae were less abundant and their occurrence coincided with maximum aphid presence. There was a low occurrence of other aphid-specific predators, i.e. Diptera: Syrphidae and Neuroptera: Chrysopidae. Arachnida varied between localities (from 35\% to 65\%). Over a five-year period, numerical responses by Orius spp., Nabis provencalis and Coccinellidae to aphids were found using polynomial regression models; however the abundance of predators was weakly explained by aphid abundance. Alfalfa, maize and winter cereals share similar aphid predator groups and these crops partially coincide in time, enabling the movement of predators among crops. The persistence of several predatory groups (Anthocoridae, Nabidae, Staphylinidae, Araneae) during most of the season suggests that alfalfa plays a major role as a reservoir of aphid predators.
\end{abstract}

\section{INTRODUCTION}

Aphids are one of the primary alfalfa pests in NE Spain. Acyrthosiphon pisum Harris, Aphis craccivora Koch and Therioaphis trifolii (Monell) are the most abundant species (Pons \& Lloveras, 1999). Although aphids are present in alfalfa fields throughout the growing season, economic densities that may cause economic damage usually occur in late July or early August (Pons, 2002). However, growers tend to apply prophylactic insecticide sprayings for aphid control from June to August after cutting, or when aphid populations are considered harmful, to prevent future direct or indirect (honeydew and sooty mould) damage. Aphid predators and parasitoids can be seriously affected by these aphicide sprayings. In spite of this hazardous situation for aphid natural enemies, there have been relatively few studies of these beneficial species in NE Iberian Peninsula (Núñez, 2002; Pons \& Starý, 2003).

This paper determines the predators associated with aphids in alfalfa, their relative occurrence and seasonal abundance, and relationships between alfalfa and aphid predators in the NE Spain arable crop landscape over several years.

\section{MATERIAL AND METHODS}

The study was conducted from 1994 to 2003 in irrigated commercial fields located in Aragon (Tauste, Zaragoza province. Zaragoza hereinafter) and Catalonia, (Almenar, Lleida province. Lleida hereinafter) in NE Spain, where alfalfa is grown as a component of the traditional crop rotation, which includes winter cereals and maize. The distance between the experimental fields in Zaragoza and those in Lleida was about $250 \mathrm{~km}$. The fields ( 1 to $5 \mathrm{ha}$ ) were representative of the local cropping system. In Zaragoza five fields were monitored from 1994 to 1996. In Lleida one field was monitored from 1997 to 2003 . All fields were sown with the most common alfalfa cultivar (Aragon) in the NE Iberian Peninsula. Traditional cropping practices, except insecticide applications, were followed in all fields. The number of alfalfa harvests ranged from 5 to 6 according to yearly conditions.

From 1994 to 1996 in Zaragoza, and from 1997 to 2001 in Lleida, fields were sampled with a D-Vac model 1-A (D-Vac and Co. Riverside, CA, USA). Although extraction efficiency is less than $100 \%$, suction samples collect a constant proportion of the population density, thus allowing valid comparisons to be made in the same habitat (Haughton et al., 2003). The method has been widely used for sampling aphids in alfalfa (Berberet \& Hutchinson, 1994) and natural enemies in different arable crops (Holland, 1998; Haughton et al., 2003), including alfalfa (Milne \& Bishop, 1987; Hossain et al., 1999). D-Vac suctions were taken from January to December following a straight line across the field by holding the nozzle flat on the ground for $30 \mathrm{~s}$. The number of D-Vac suction points varied according to the field size, and ranged from 5 to 15 , each sample included two $30 \mathrm{~s}$. sub-samples (each suction covers $0.092 \mathrm{~m}^{2}$ ). Sampling periodicity was monthly during the non-productive period of alfalfa (from January to April and October to December) and 2-4 samplings per month during the productive period (May to September). When more than 1 sample per month was taken, the number of individuals per sample was averaged on a per month basis. However, during the period with the highest density of aphids (July and August) we split the month in two fifteen-day periods and 2 values per month are reported. Samples were 
taken between 11 a.m. and 1 p.m. to avoid dew on plants. The samples were kept in a refrigerator and taken to the laboratory where adult and immature predators were identified and counted. In the Lleida samples the aphid species and numbers were also recorded. Numbers of insects per D-Vac sample were divided by the sampled surface to estimate the number of insects per square metre.

In 2002 and 2003 only sweep-net samples were taken. Sweet net sampling was carried out from April to September with a 30 $\mathrm{cm}$ diameter sweep-net. Samples were also taken at 10 "points" on a straight line across the field and the number of sweeps for each sample was five. Samples were taken between 11 a.m. and 1 p.m. The samples were kept in a refrigerator and taken to the laboratory where predators were identified and counted.

The most abundant predators of each taxon (occurrence $>$ $5 \%$ ) were identified to species using specific keys or with the help of taxonomists from the Iberian Peninsula.

To determine if a relationship existed between the abundance of the main predatory groups and the abundance of aphids, a polynomial regression model was fit to all monthly data collected in Lleida during the period 1997-2001. The model included linear, quadratic and cubic variables to describe linear or more complex numerical responses. Regression analyses were done using SAS (SAS Institute, 2000).

To determine the relationships between crops and aphid predators, the seasonal abundance of three of the most abundant predators recorded in the present study in Lleida, Orius sp., $N$. provencalis and coccinellids, were compared with those recorded on maize in the same area at the same period (Albajes \& Pons, unpubl.).

\section{RESULTS}

\section{Predator occurrence and seasonal abundance}

Aphid predators collected by D-Vac sampling belonged to both Insecta and Arachnida. Arachnids represented $35 \%$ of the predatory arthropods collected in Lleida and $65 \%$ in Zaragoza. Among the insects, there were adults and immatures of Heteroptera, Dermaptera, Neuroptera, Coleoptera and Diptera (Table 1). Heteroptera were the most abundant group, followed by Coleoptera. Individuals of both orders represented more than $95 \%$ of the predators that may include aphids in their diet. There was a low occurrence of Neuroptera $(<3 \%)$ and Diptera $(1 \%)$, Dermaptera were relatively scarce $(<0.5 \%)$ (Table 1$)$.

\section{Arachnida}

Several species of arachnida were collected, including spiders, opilions and mites, among the latter mainly Allothrombium sp. Because no differentiation among families was made in arachnids, the seasonal abundance of this predatory group is not presented, although spiders were recorded throughout the year.

\section{Heteroptera}

Among Heteroptera, the Anthocoridae, Nabidae, and Miridae were the most abundant families (Table 1). Other heteropterans collected included some predatory Lygaeidae. Four species of Anthocoridae occurred at $>5 \%$; all of them belonged to the genus Orius, Orius majusculus Reuter and Orius niger Wolf were the predominant species. The most common nabid was Nabis provencalis Remane, in Lleida it was the only species recorded. Miridae populations were composed mainly of Lygus sp., Adelphocoris lineolatus Goeze and Deraeocoris serenus Douglass Scott.

Miridae were the prevalent group of heteropterans in Zaragoza (22.8\%), but were the least abundant in Lleida $(8.5 \%)$ where damsel bugs (Nabidae) were the most prevalent group (33\%). The average occurrence of Orius spp. was approximately $15 \%$ in both sampling areas although in Zaragoza the occurrence ranged from 10 to $20 \%$, whereas in Lleida the range was 4 to $46 \%$.

Orius spp. were found in alfalfa fields throughout the year in Zaragoza and Lleida (Fig. 1). The density of Orius spp. peaked in the second half of July or August when nymphs were very abundant. The main damsel bug spe-

TABLE 1. Relative occurrence (\%) of the main aphidophagous predator groups of insects (adults + immature) at two locations in the northeast Iberian Peninsula. $\mathrm{n}=$ total number of insects $/ \mathrm{m}^{2}$ collected throughout the year.

\begin{tabular}{|c|c|c|c|c|c|c|c|c|c|c|c|}
\hline \multirow[b]{2}{*}{ Predator group } & \multicolumn{4}{|c|}{ Zaragoza } & \multicolumn{6}{|c|}{ Lleida } & \multirow{2}{*}{$\begin{array}{l}\text { Overall } \\
\text { average }\end{array}$} \\
\hline & 1994 & 1995 & 1996 & $\begin{array}{l}\text { Average } \\
\text { 1994-96 }\end{array}$ & 1997 & 1998 & 1999 & 2000 & 2001 & $\begin{array}{l}\text { Average } \\
1997-01\end{array}$ & \\
\hline Heteroptera & 44.45 & 59.45 & 41.96 & 50.40 & 62.07 & 47.86 & 65.98 & 53.90 & 67.58 & 60.66 & 55.45 \\
\hline Anthocoridae & 12.70 & 18.91 & 9.43 & 14.60 & 3.77 & 20.06 & 20.15 & 15.20 & 45.75 & 19.04 & 16.68 \\
\hline Nabidae & 12.83 & 7.98 & 15.45 & 11.40 & 54.19 & 19.32 & 32.07 & 20.64 & 15.76 & 32.44 & 21.69 \\
\hline Miridae & 16.16 & 30.80 & 16.80 & 22.80 & 3.20 & 7.48 & 13.03 & 17.06 & 5.65 & 8.43 & 15.92 \\
\hline Others & 2.76 & 1.76 & 0.28 & 1.60 & 0.30 & 1.40 & 0.73 & 1.03 & 0.42 & 0.75 & 1.16 \\
\hline Dermaptera & 0.00 & 0.00 & 0.00 & 0.00 & 0.38 & 0.00 & 0.18 & 0.00 & 0.00 & 0.16 & 0.07 \\
\hline Neuroptera & 2.12 & 1.89 & 4.75 & 2.71 & 0.96 & 6.12 & 2.04 & 3.98 & 3.03 & 2.80 & 2.76 \\
\hline Chrysopidae & 2.12 & 1.26 & 3.97 & 2.22 & 0.47 & 5.96 & 2.04 & 3.61 & 2.60 & 2.47 & 2.34 \\
\hline Hemerobiidae & 0.00 & 0.63 & 0.78 & 0.49 & 0.49 & 0.16 & 0.00 & 0.37 & 0.43 & 0.33 & 0.40 \\
\hline Coleoptera & 51.95 & 38.32 & 52.38 & 46.00 & 34.98 & 44.13 & 30.70 & 39.24 & 29.26 & 35.19 & 40.71 \\
\hline Coccinellidae & 4.81 & 5.13 & 13.82 & 7.30 & 3.56 & 5.47 & 6.36 & 5.45 & 7.00 & 5.29 & 6.33 \\
\hline Carabidae & 6.09 & 8.53 & 10.99 & 8.50 & 1.05 & 1.02 & 1.55 & 1.18 & 1.00 & 1.14 & 4.90 \\
\hline Staphylinidae & 41.05 & 24.66 & 27.57 & 30.20 & 30.37 & 37.64 & 22.78 & 32.61 & 21.26 & 28.75 & 29.50 \\
\hline Diptera & 1.48 & 0.34 & 0.92 & 0.80 & 1.59 & 0.89 & 1.09 & 2.21 & 0.14 & 1.20 & 1.01 \\
\hline Syrphidae & 1.48 & 0.34 & 0.92 & 0.80 & 1.59 & 0.89 & 1.09 & 2.21 & 0.14 & 1.20 & 1.01 \\
\hline $\mathrm{n}$ (individuals $/ \mathrm{m}^{2}$ ) & 678 & 1034 & 614 & 2326 & 735 & 345 & 382 & 314 & 433 & 2209 & 4535 \\
\hline
\end{tabular}


Orius spp.

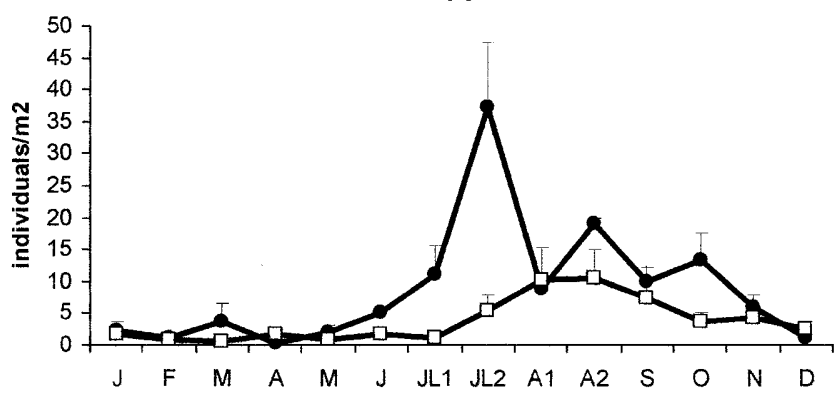

N. provencalis

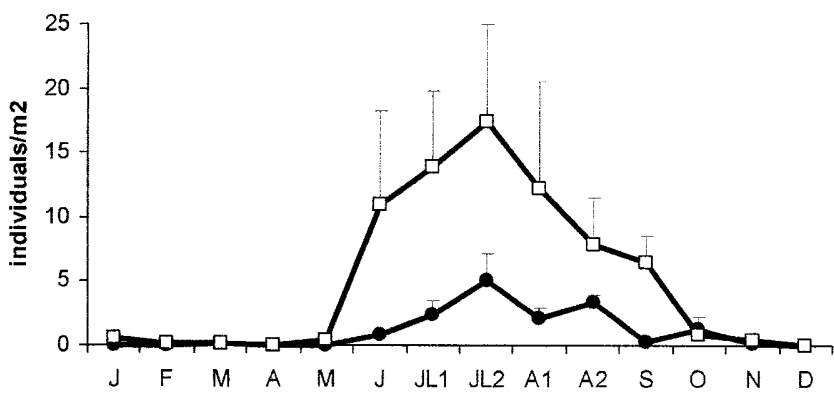

Miridae

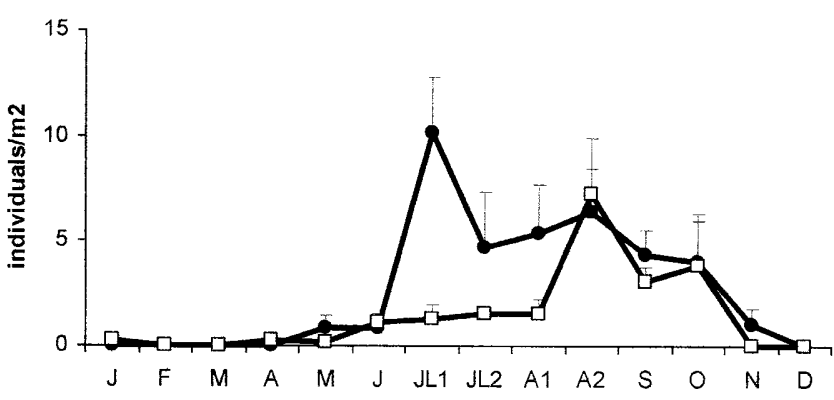

month

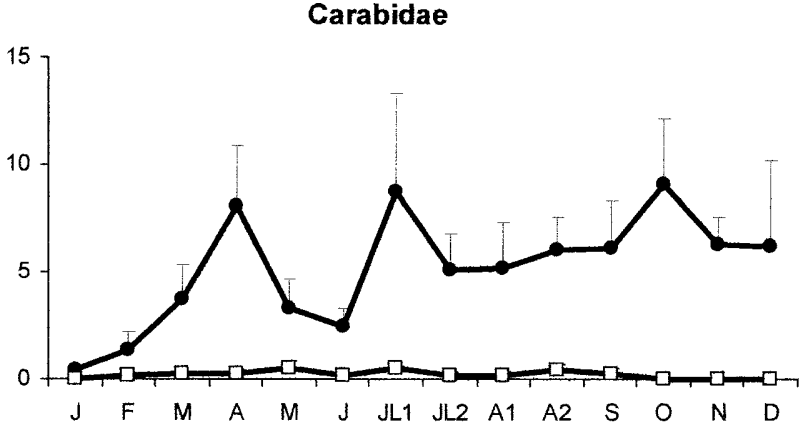

Staphylinidae

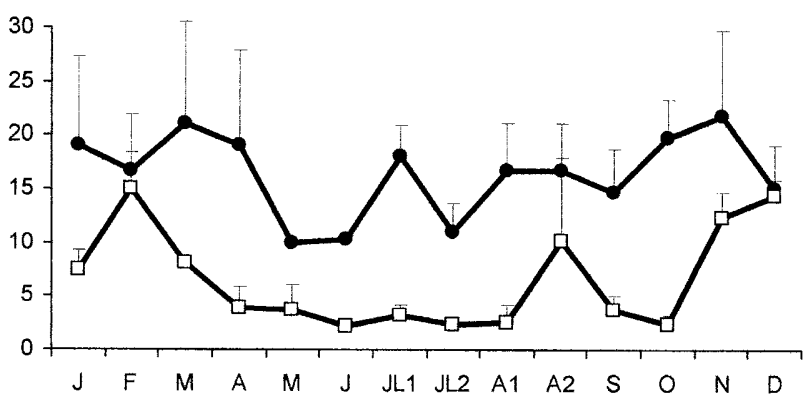

Coccinellidae

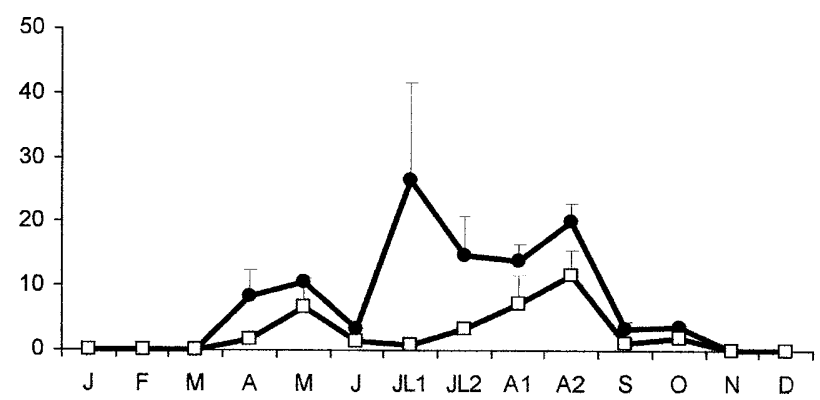

month

\section{-ZARAGOZA $-\square-$ LLEIDA}

Fig. 1. Seasonal abundance of the main heteropterans (Orius sp., Nabis provencalis and Miridae) and coleopterans (Coccinellidae, Carabidae and Staphylinidae) that potentially prey on aphids in alfalfa fields (D-Vac sampling) from two locations of the NE Iberian Peninsula. Values are monthly averages ( \pm s.e.) of three years in Zaragoza (1994-1996) and five years in Lleida (1997-2001).

cies, N. provencalis, showed a similar pattern with high number of nymphs occurring in summer. However, during winter very low densities of $N$. provencalis were found in Lleida, and no individuals were collected in Zaragoza. Miridae occurred mainly from May to November at both localities, populations peaked in the first half of July in Zaragoza but in the second half of August in Lleida.

\section{Coleoptera}

Coccinellidae, Carabidae and Staphylinidae were the main families of Coleoptera occurring in the alfalfa fields (Table 1). Other predatory Coleoptera such as Cantharidae were occasionally collected but are not presented in the results.

Hippodamia variegata Goeze, Coccinella septempunctata L. and Scymnus spp. constituted more than $90 \%$ of the ladybirds (Coccinellidae), whereas the other six species recorded occurred in less than $2 \%$ each. Ladybirds were found from late April to October. The relative occurrence of ladybirds was quite similar in Zaragoza and Lleida and averaged $6.5 \%$ of all predators in the whole region (Table 1). However, the seasonal abundance varied between the two locations (Fig. 1). The two peaks in Lleida coincided with the maximum aphid density. Because most of the individuals collected were larvae that were not determined to species, coccinellids have been considered as a single group.

Only adult Carabidae and Staphylinidae were collected. Within Carabidae, three species occurred at percentages $>5 \%$ for the taxon (Demetrias atricapillus L., Tachyura sexstriata Duftschmid and Eotachys bistriatus Duftschmid), but nearly 20 different species were col- 


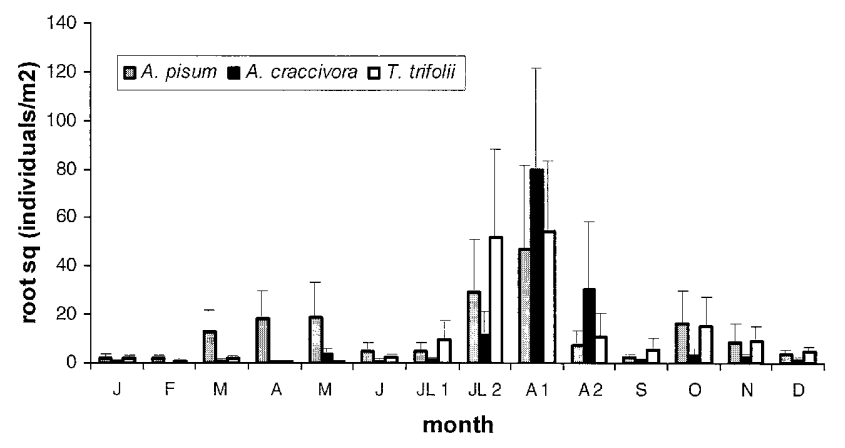

Fig. 2. Seasonal abundance of the three most abundant aphid species (Acyrthosiphon pisum, Aphis craccivora and Therioaphis trifolii) in alfalfa fields (D-Vac sampling) of Lleida. Values are monthly averages ( \pm s.e.) of five years (1997-2001).

lected. Ground beetles (Carabidae) were more abundant in Zaragoza than in Lleida (Fig. 1). The most commonly collected ground beetle in Lleida was D. atricapillus, whereas in Zaragoza it was T. sexstriata.

Rove beetles (Staphylinidae) constituted the most abundant predatory group (nearly $30 \%$ of the total predators) and although more than 40 species were collected, only 6 species occurred at percentages $>5 \%$ of the taxon. The relative occurrence of rove beetles was similar in Lleida and Zaragoza. The presence of rove beetles was observed throughout the year but, in contrast with the other predatory groups, the highest abundance occurred in autumn and winter (Fig. 1).

\section{Neuroptera, Diptera and Dermaptera}

The relative occurrence of Neuroptera was very low (2.5\%). Chrysopidae, especially Chrysoperla carnea Stephens group (Henry et al., 2001), and relatively few Hemerobiidae (mainly Micromus angulatus Stephens) were identified. The relative occurrence of lacewings was similar at both locations. Syrphidae was the main dipteran family found in Zaragoza and in Lleida. Eupeodes corollae F., Sphaerophoria scripta L. and Episyrphus balteatus De Geer were the most common species. Larvae of Cecidomyiidae (presumably Aphidoletes aphidimyza) were rarely recorded. One species of Dermaptera (Forficula auricularia L.) occurred in Lleida in two of the five years monitored.

\section{Sweep-net samples}

The same predator groups collected in the D-Vac samples were observed in the sweep-net samples. Only $10 \%$ of predators collected with sweep-nets were arachnida. Heteroptera represented more than $85 \%$ of the insects collected and Coleoptera $11 \%$ (nearly $10 \%$ of predators collected were Coccinellidae). These differences were probably due to the different strata of the habitat sampled by sweep-net and D-Vac. Therefore, data from sweep-net samples were used only to support the yearly patterns of the seasonal abundance recorded with the D-Vac samples. Sweep-net samples confirmed some aspects of the seasonal abundance of coccinellids: for example, the occurrence of two peaks of maximum density, the first in May
TABLE 2. Polynomial regression models of predator and aphid abundance in one field in Lleida over a 5 years period (1997-2001). Only adult Carabidae and Staphylinidae were caught. Immature Araneae were not distinguished from adults.

\begin{tabular}{lccc}
\hline \multirow{2}{*}{ Predator } & \multicolumn{3}{c}{ Regression statistics } \\
\cline { 2 - 4 } & $\mathrm{F}$ & $\mathrm{P}$ & $\mathrm{R}^{2}$ \\
\hline Adult & & & \\
$\quad$ Orius spp. & 6.70 & 0.0006 & 0.25 \\
N. provencalis & 8.70 & $<0.0001$ & 0.30 \\
Miridae & 0.02 & 0.9950 & 0.01 \\
Coccinellidae & 0.04 & 0.9901 & 0.01 \\
Carabidae & 0.58 & 0.6286 & 0.03 \\
Staphylinidae & 1.98 & 0.1262 & 0.09 \\
Araneae & 1.44 & 0.2414 & 0.06 \\
Immature & & & \\
$\quad$ Orius spp. & 0.18 & 0.9117 & 0.01 \\
$\quad$ N. provencalis & 2.98 & 0.0383 & 0.13 \\
Miridae & 0.03 & 0.9764 & 0.01 \\
Coccinellidae & 3.53 & 0.0201 & 0.15 \\
\hline
\end{tabular}

or June and the second in August. It was also noted that the predominant species during the first peak was $C$. septempunctata, whereas $H$. variegata was the predominant species during the second peak.

\section{Aphid seasonal abundance}

Three aphid species were recorded: A. craccivora, $A$. pisum and $T$. trifolii. All three species occurred throughout the year, but population densities remained low during the autumn, winter and spring. Two peaks in aphid abundance were recorded, A. pisum was the main component of the aphid peak population during May. There was an exponential growth in aphid populations in mid July and the second peak was reached in the first half of August: A. craccivora and T. trifolii were the predominant species (Fig. 2).

\section{Relationships between aphids and predatory groups}

Polynomial regression models describing the numerical response by predators to aphids were significant for adults of Orius spp. and $N$. provencalis, and for nymphs of $N$. provencalis and larvae of coccinellids but $\mathrm{R}^{2}$ values ranged form 0.13 to 0.30 for these relationships (Table 2). Numerical response models included quadratic and/or cubic powers of aphid abundance as predictor variables, indicating that rates of increase in predator abundance varied nonlinearly with aphid abundance. No significant models describing the numerical response of Miridae, Carabidae, Staphylinidae and Arachnida to aphids were found.

\section{Aphid predators in alfalfa and maize}

Densities of Orius spp. started to increase and peaked in maize before they did in alfalfa (Fig. 3). The maximum density of Orius spp. in maize occurred during the pollen shed (mid July). After this period there was a decrease in Orius spp. numbers in maize and an increase in numbers in alfalfa within 2-4 weeks, when aphid densities were high. 
Orius spp.

1997

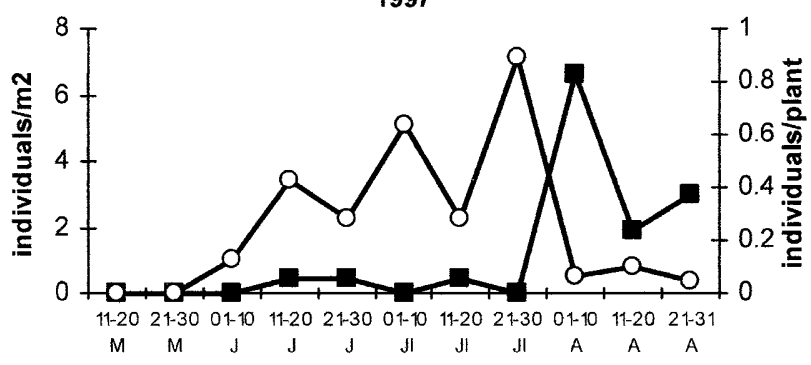

1998
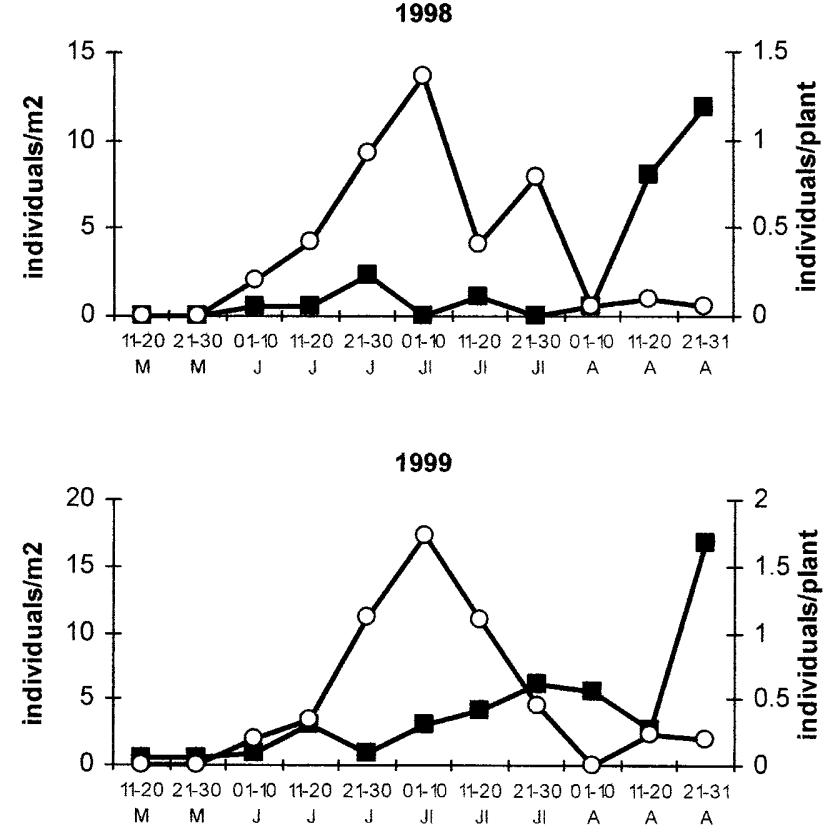

2000

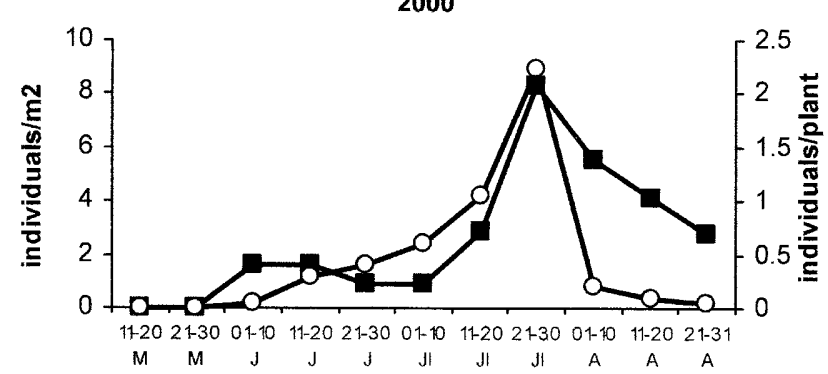

Date
N. provencalis

1997

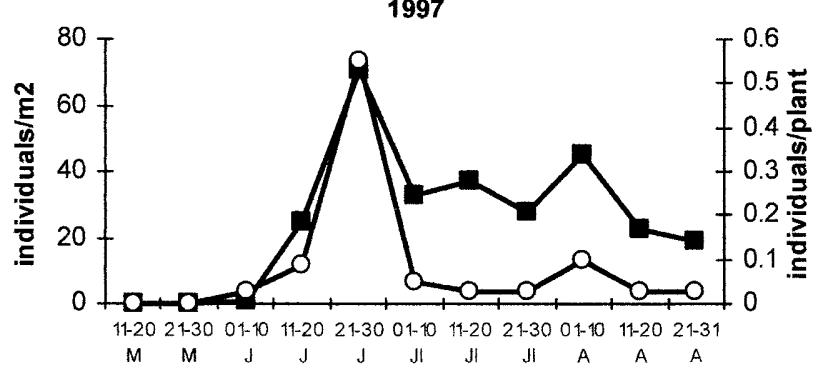

1998

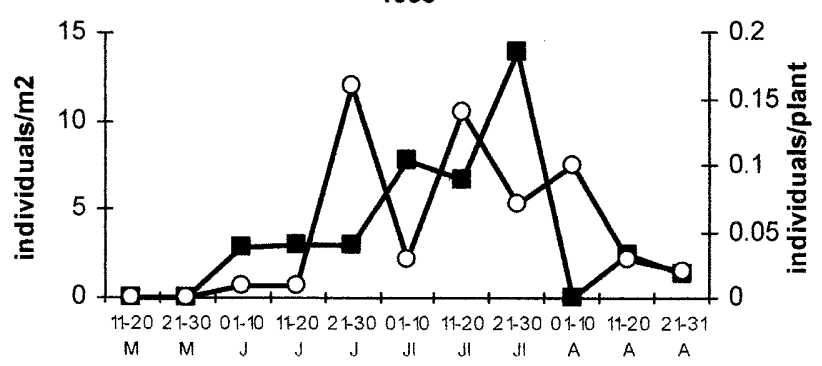

1999

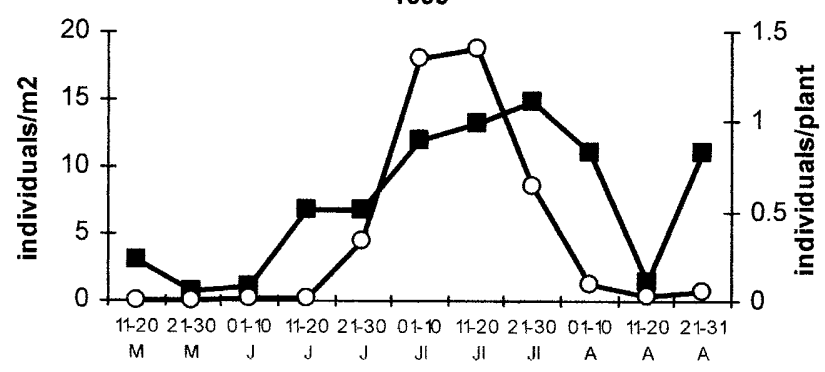

2000

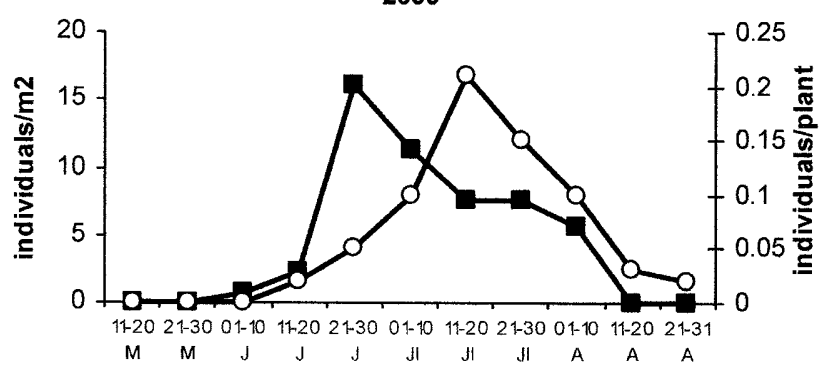

Date

Fig. 3. Seasonal abundance of Orius sp. and Nabis provencalis in alfalfa and in maize fields from May to August in Lleida, 1997-2000. Alfalfa values are expressed as individuals $/ \mathrm{m}^{2}$ whereas maize values are expressed as individuals/plant.

The seasonal abundance of nabids in alfalfa and maize showed similar patterns (Fig. 3), with the population increase and peaks occurring at nearly the same time.

Coccinellids were detected on both crops when aphids were present. Coccinellids peaked in maize during May and early June, when aphid densities peaked. Relatively few coccinellids were found in alfalfa in May and early June when aphid densities were relatively low. From midJune to mid-July, aphids and coccinellids were very rare on alfalfa. However, coccinellids increased from the second half of July during the period of highest aphid abundance.

\section{DISCUSSION}

The predatory fauna potentially feeding on aphids recorded at the two localities of this study revealed that it was primarily comprised of generalist predators including Araneae, Heteroptera, Neuroptera and the Coleopteran 
families Carabidae and Staphylinidae, rather than aphidspecific species, i.e. Coccinellidae or Syrphidae.

Suppression of agricultural pests by natural enemies is the result of density dependent processes including the functional (when the natural enemy increases its attack rate at increasing pest densities) and numerical responses (Elliot et al., 2002). Numerical responses investigated in the present study for several predatory groups showed that two heteropterans (Orius spp. and $N$. provencalis) and Coccinellidae were more abundant in alfalfa fields when aphid density increased. Previous studies have demonstrated a numerical response by several predatory groups, e.g, coccinellids (Neuenschwander et al., 1975; Frazer et al., 1981; Elliott et al., 2002) or Nabidae (Elliott et al., 2002) to aphids in alfalfa fields. Neuenschwander et al. (1975) documented that polyphagous Heteroptera were important in aphid control, when coccinellids were inactive or left the fields. Frazer et al. (1981) concluded that while early season populations of aphids can be limited by coccinellid predation alone, populations occurring later in the year are most often regulated by the combined action of several predators including Orius spp. However, Snyder \& Ives (2002) did not observe a density dependent relationship between generalist predators (including Orius spp., Nabis spp.) and A. pisum, but they reported significant reductions of aphid densities by these predators. Orius sp. and N. provencalis were $50 \%$ of the insects collected in the present study. Coccinellids occurred mainly when aphid populations peaked, suggesting that these predators may play a limited role in keeping aphid densities under economic levels in the study area.

Even though regression models of predators to aphids were significant for adults of Orius spp., adults and nymphs of $N$. provencalis and larvae of coccinellids, these models explained a low percentage of the observed variation, indicating that factors other than the prey abundance were involved in determining the number of predators in alfalfa fields. Weather factors (temperature, rainfall and others) may influence the density of aphids and could affect predatory species. Additionally, the structure of the landscape matrix may affect predator abundance. Elliott et al. (2002) reported that landscape variation was an important factor determining predator abundance, but other factors, including the abundance of alternative prey should be considered, especially for polyphagous predators like Orius spp. and N. provencalis.

The yearly overall occurrence of Orius spp. in alfalfa suggests that this crop is a good reservoir for this predatory group. The presence of both adults and nymphs in summer indicated that Orius spp. reproduce in alfalfa. Furthermore, alfalfa is a good habitat for overwintering, as is shown by the occurrence of adults from November to March. Nabis provencalis reproduced in alfalfa fields. In contrast to Orius spp., the low densities of $N$. provencalis recorded during the winter indicate that this species does not usually use alfalfa as a winter refuge. Nabis provencalis overwinters in field margins (Núñez, 2002).
Although Carabidae, Staphylinidae and Araneae were not numerically related to alfalfa aphids in the present study, their occurrence throughout the year indicated the role of alfalfa as reservoir for these predators. These predators have been reported to be active aphid predators in winter cereals and maize (Lövei \& Szentkiralyi, 1984; Asín \& Pons, 1988; Sunderland, 1988; Brewer \& Elliott, 2004), the other arable crops grown in NE Spain. Alfalfa does not appear to be a reservoir of coccinellids, but is an "insectary crop" because these predators occur on alfalfa only when aphids are abundant.

When compared with maize and winter cereals, which were previously studied in NE Spain (Asín \& Pons, 1998; Pons \& Eizaguirre, 2000; Albajes et al. 2003), alfalfa shows a greater diversity of predatory species. Approximately 20 species of aphid predators have been recorded in maize and winter cereal, which is lower than the figure recorded in alfalfa in the present study. However, comparing the main groups of aphidophagous predators in alfalfa with those found in maize (Asín \& Pons, 1998; Albajes et al., 2003), including Bt-maize (De la Poza, 2005), and winter cereals (Pons \& Eizaguirre, 2000) shows a high degree of similarity, even though the aphid species in maize and winter cereals are different from those in alfalfa.

Although more detailed studies are needed, the coincidence in time of different arable crops in the landscape suggests movement of predatory species between crops. The results of the present study allow us to hypothesize about movement of aphid predators between alfalfa and maize, and by extension to other arable crops. For example, Orius spp. spend the autumn and winter in alfalfa, which becomes a source of individuals dispersing in spring to maize, winter cereals, and fruit orchards where Orius spp. are common in spring (Sarasúa et al., 1984; Pons \& Eizaguirre, 2000; Albajes et al., 2003). Orius spp. populations develop in maize, reaching their maximum population during the pollen shed; subsequently, they move to alfalfa where they reproduce during late summer and overwinter. The coincidence of phenology of $N$. provencalis on maize and alfalfa suggests that this species colonizes maize and alfalfa at nearly the same time, probably emigrating from overwintering sites in alfalfa fields margins (Núñez, 2002).

ACKNOWLEDGEMENTS. This study was funded by the Comisión Interministerial de Ciencia y Tecnología (Projects AGF96-0482, AGF99-0782) and by the Ministry of Science and Technology (Plan Nacional I+D+I, Project AGL 2002-204) of the Spanish Government. Eva Núñez was funded by a $\mathrm{PhD}$ grant from the Generalitat de Catalunya. We would like to thank M. Goula, R. Outerelo, J. Vives and J. Riudavets for their help in the species determination and R. Blanco for helping in statistical analysis. We would also like to thank two anonymous referees for the criticism of the manuscript.

\section{REFERENCES}

Albajes R., López C. \& Pons X. 2003: Predatory fauna in corn fields and response to imidacloprid seed treatment. J. Econ. Entomol. 96: 1805-1813. 
Asín L. \& Pons X. 1998: Aphid predators in maize fields. IOBC/WPRS Bull. 21(8): 163-170.

Berberet R.C. \& Hutchinson W.D. 2000: Sampling methods for insect management in alfalfa. In Pedigo L.P \& Buntin G.D. (eds): Handbook for Sampling Methods for Arthropods in Agriculture. CRC Press, Boca Raton, FL, pp. 357-381.

Brewer M.J. \& ElLIOTt N.C. 2004: Biological control of cereal aphids in North America and mediating effects of host plant and habitat manipulations. Annu. Rev. Entomol. 49: 219-242.

De la Poza M., Pons X., Farinós G.P., López C., Ortego F., Eizaguirre M., Castañera P. \& Albajes R. 2005: Impact of farm-scale Bt maize on abundance of predatory arthropods in Spain. Crop Prot. 24: 677-684.

Elliott N.C., Kieckhefer R.W., Michels G.J. Jr. \& Giles K.L. 2002: Predator abundance in alfalfa fields in relation to aphids, within-field vegetation, and landscape matrix. Environ. Entomol. 31: 253-260.

Frazer B.D., Gilbert N., Nealis V. \& Raworth D.A. 1981: Control of aphid densities by a complex of predators. Can. Entomol. 113: 1035-1041.

Haughton A.J., Champio G.T., Hawes C., Heard M.S., Brooks D.R., Bohan D.A., Clark S.J., Dewar A.M., Firbank L.G., Osborne J.L., Perry J.N., Rothery P., Roy D.B., Scott R.J., Woiwod I.P., Birchall C., Skellern M.P., Walker J.H., Baker P., Browne E.L., Dewar A.J.G., Garner B.H., Haylock N.S., Horne S.L., Mason N.S., Sands R.J.N. \& Walker M.J. 2003: Invertebrate responses to the management of genetically modified herbicide-tolerant and conventional spring crops. II. Within-field epigeal and aerial arthropods. Phil. Trans. R. Soc. Lond. (B) 358: 1863-1877.

Henry C.S., Brooks S.J., Thierry D., Duelli P. \& Johnson J.B. 2001: The common green lacewing (Chrysoperla carnea s.lat.) and the sibling species problem. In Mc Ewen P., New T.R. \& Whittington A.E. (eds): Lacewings in the Crop Environment. Cambridge University Press, Cambridge, pp. 29-42.

Holland J.M. 1998: The effectiveness of exclusion barriers for polyphagous predatory arthropods in wheat. Bull. Entomol. Res. 88: 305-310.

Hossain Z., Gurr G.M., Wratten S.D. 1999: Capture efficiency of natural enemies from tall and short vegetation using vacuum sampling. Ann. Appl. Biol. 135: 463-467.
Lövei G.L. \& SzentKiralyi F. 1984: Carabids climbing maize plants. Z. Angew. Entomol. 97: 107-110.

Milne W.N. \& Bishop A.L. 1987: The role of predators and parasites in the natural regulation of Lucerne aphids in Eastern Australia. J. App. Ecol. 24: 893-905.

Neuenschwander P., Hagen K.S. \& Smith R.F. 1975: Predation on aphids in California's alfalfa fields. Hilgardia 43: 53-78.

NúÑEZ E. 2002: La alfalfa como reservorio de enemigos naturales. $\mathrm{PhD}$ thesis, Universitat de Lleida, $240 \mathrm{pp}$.

Pons X. 2002: Niveles poblacionales de pulgones en alfalfa libre de tratamientos aficidas. In Chocarro C., Santiveri F., Fanlo R., Bovet I. \& Lloveras J. (eds): Producción de Pastos, Forrajes y Céspedes. Ediciones de la Universitat de Lleida, Lleida, pp. 349-353.

Pons X. \& Eizaguirre M. 2000: Els enemics naturals de les plagues de cultius de cereals a Catalunya. In Ticó J. (ed.): Enemics Naturals de Plagues en Diferents Cultius a Catalunya. Dossier Agraris 6. Institució Catalana d'Estudis Agraris, Barcelona, pp. 105-116.

Pons X. \& Lloveras J. 1999: Densidad poblacional de pulgones en cultivares de alfalfa en los regadíos de Lleida. Investig. Agr. Prod. Prot. Veget. 14: 405-413.

Pons X. \& Starý P. 2003: Spring aphid-parasitoid (Hom., Aphididae, Hym. Braconidae) associations and interactions in a Mediterranean arable crop ecosystem, including Bt maize. J. Pest Sci. 76: 1-6.

Sarasúa M.J., Solà N., Artigues M. \& Avilla J. 1994: The role of Anthocoridae in the dynamics of Cacopsylla pyri populations in a commercial orchard without pesticides. $I O B C /$ WPRS Bull. 17: 138-141.

SAS Institute 2000: SAS/STAT User's Guide, Version 8. SAS Institute, Cary, NC.

SNYDER W.E. \& IvES A.R. 2002: Interactions between specialist and generalist natural enemies: parasitoids, predators, and pea aphid biocontrol. Ecology 84: 91-107.

Sunderland K.D. 1988: Carabidae and other invertebrates. In Minks A.K. \& Harrewijn P. (eds): Aphids, their Biology, Natural Enemies and Control. Vol. 2B. Elsevier, Amsterdam, pp. 293-310.

Received September 10, 2004; revised March 31, 2005; acceptedApril 6, 2005 